\title{
Effect of Light Emitting Diodes Treatment on Growth and Quality of Lettuce (Lactuca sativa L. 'Oak Leaf')
}

\author{
Yong-Seub Shin ${ }^{1 *}$, Mun-Jung Lee ${ }^{1}$, Eun-Sook Lee ${ }^{1}$, Joon-Hyung Ahn ${ }^{1}$, Min-Ki Kim ${ }^{1}$, Ji-Eun Lee ${ }^{1}$, \\ Han-Woo Do ${ }^{1}$, Joung-Do Cheung ${ }^{1}$, Jong-Uk Park ${ }^{1}$, Young-Ghul Um ${ }^{2}$, So-Deuk Park ${ }^{1}$ and Jang-Heui Chae ${ }^{1}$ \\ ${ }^{1}$ Gyeongsangbukdo Agricultural Research \& Extension Services, Daegu 702-708, Korea \\ ${ }^{2}$ National Institute of Horticultural and Herbal Science, RDA, Suwon 440-706, Korea
}

Received August 31, 2013 /Revised December 31, 2013 /Accepted January 6, 2014

\begin{abstract}
The objective of this study was to elucidate the effect of light-emitting diode treatment on early growth and inorganic elements in leaf lettuce (Lactuca sativa L. 'Oak Leaf'). In changes to leaf morphology, shoot elongation and hypocotyl length showed poor growth under red light irradiation, while red+blue light irradiation induced shorter plant height and more leaves, resulting in increased fresh weight. With respect to Hunter's color and SPAD values, lettuce seedlings grown under red+ blue and fluorescent light irradiation had a higher $a^{*}$ value but showed no other changes to SPAD values. Interestingly, redness in relative chlorophyll content was 1.4 times higher under red+blue light irradiation. Inorganic element $(\mathrm{N}, \mathrm{Ca}, \mathrm{Mg}$, and $\mathrm{Fe})$ and ascorbic acid concentrations increased in lettuce plants grown under LED light irradiation compared to those of lettuce grown under fluorescent light, which showed a higher $\mathrm{P}$ content. In conclusion, red+blue light irradiation, which stimulates growth and higher nutrient uptake in leaf lettuce, could be employed in containers equipped with LEDs.
\end{abstract}

Key words : Growth, Light emitting diodes (LEDs) lettuce, minerals

\section{Introduction}

Lettuce (Lactuca sativa L.) belongs to a member of the compositae, which is one of the major vegetable in the world. Lettuce is representative rice wrapped vegetable in Korea [5]. In Korea, leaf lettuce is commonly used as "wrap-up vegetable" with perilla (Perilla frutescens), kale (Brassica oleracea L. var. acephala), and pak-choi (B. rapa L. var. chinensis) [9] and is widely grown commercially in greenhouses using hydroponic culture [6].

Light emitting diodes (LEDs) have been proposed as a photosynthetic radiation source for space flight growing systems and as a more efficient source for terrestrial controlled-environment agriculture facilities [2]. It showed that lettuce and other dicotyledon plants developed excessive hypocotyl elongation when grown under high-intensity red-emitting LEDs as the sole source of irradiance. LEDs

\footnotetext{
*Corresponding author

Tel : +82-54-931-6789, Fax : +82-54-931-1753

E-mail : sys1962@korea.kr

This is an Open-Access article distributed under the terms of the Creative Commons Attribution Non-Commercial License (http://creativecommons.org/licenses/by-nc/3.0) which permits unrestricted non-commercial use, distribution, and reproduction in any medium, provided the original work is properly cited
}

are a promising electric light source for space-based plant growth chambers because of their small mass and volume, solid-state construction, superior safety, and longevity [1, 2]. The electrical efficiency $\left(\mu \mathrm{mol} \cdot \mathrm{J}^{-1}\right)$ of gallium aluminum arsenide (GaAlAs) red LEDs is reportedly greater than that of fluorescent lamps and comparable to high-pressure sodium lamps [1].

Commonly available red LEDs emit a narrow-spectrum of light (660 nm with $25 \mathrm{~nm}$ bandwidth at half peak height), which closely matches a peak absorbance of chlorophyll [7]. Although red LEDs have great potential for use as a light source to drive photosynthesis, plants are adapted to utilize a wide-spectrum of light to control photomorphogenesis. Previous reports indicate that a minimum amount (20-30 $\mu \mathrm{mol} \cdot \mathrm{m}^{-2} \cdot \mathrm{s}^{-1}$ ) of blue light in broad-spectrum lamps is necessary to achieve normal growth and morphology. This blue light requirement appears to be a species-specific response [12]. Tests with the addition of blue fluorescent (BF) light to narrow-band red LEDs $(660 \mathrm{~nm})$ support the findings with broad-spectrum lamps. Despite the increasing popularity of red LEDs as a radiation source for growing plants, information is available for only a few plant species that directly compares growth and yield under red LEDs (with and without supplemental blue light) with those under the 
broad spectrum light. Hence, the purpose of this study is to evaluate the effects of different LEDs on early seedling growth, leaf color, inorganic elements, ascorbic acid and SPAD value in lettuce.

\section{Materials and Methods}

\section{Lettuce growing}

Lettuce (Lactuca sativa L., cv. 'Oak Leaf') seeds were incubated at $4^{\circ} \mathrm{C}$ on moistened germination paper for 2 days and germinated seeds were grown in peat substrate with a with a $6 \mathrm{~h} / 18 \mathrm{~h}$ (day/night) photoperiod and an average ambient temperature of $20 / 16^{\circ} \mathrm{C}$ (day/night). Each plastic culture tray $(10 \mathrm{~cm} \mathrm{~W} \times 35 \mathrm{~cm} \mathrm{~L})$ contained three plants spaced $12 \mathrm{~cm}$ apart which is an effective planting density of 75 plants per $\mathrm{m}^{2}$ ). Evapotranspiration losses of water were replenished daily by adding deionized water to the nutrient solution reservoir. Air temperature, relative humidity, and $\mathrm{CO}_{2}$ levels were maintained in growth chambers at $20^{\circ} \mathrm{C}, 60 \%$, and $500 \mathrm{mg} \cdot 1^{-1}$ respectively. The referred ambient parameters of the room were maintained throughout the experiment duration. Each treatment comprises a $60 \times 60 \mathrm{~cm}$ illuminated growth area.

\section{LED treatment}

Lettuce seedlings were grown for 30 day with photosynthetic photon flux (PPF) maintained at near $300 \mu$ $\mathrm{mol} \cdot \mathrm{m}^{-2} \cdot \mathrm{s}^{-1}$. Levels of PPF were measured with a quantum sensor (Model LI-180, LI-COR, Lincoln) calibrated with a spectro-radiometer (Model LI-1800, LI-COR) to enable accurate readings for LEDs. The photosynthetic photon flux (PPF) in Red, Blue, Red+Blue, Fluorescent, Ultra violet, Far red was 172, 192, 169, $163 \mu \mathrm{mol} \cdot \mathrm{m}^{-2} \cdot \mathrm{s}^{-1}, 5.1^{-3}, 497.7 \mathrm{w} \cdot$ $\mathrm{m}^{-2}$. The maximum peak of each LED radiation showed red (450-660 nm), far-red $(730 \mathrm{~nm})$, blue $(450 \mathrm{~nm})$, blue-red
(450+660 nm), Ultra violet (350 nm), Fluorescent as control light.

Leaf surface were measured with a Minolta CR-200b colorimeter (Minolta, Ramsey, NJ) Three matured leaves per plant, in the upper third of the canopy, were measured on half of the plants of each plant under grown different LED radiation treatments. Leaf $L^{*} a * b *$ values were measured at the midpoint between the distal and basal ends of leaf. Chlorophyll meter readings (SPAD values) were repeatedly taken ten times at the centre of the leaves throughout the experiments.

For determining inorganic elements, about $2 \mathrm{~g}$ lettuce powder was directly weighed in a porcelain crucible. The sample was preheated on a Bunsen burner until smoke was no longer observed. The crucible was placed in a cold muffle furnace. The temperature of the muffle was raised from $50^{\circ} \mathrm{C} / 30 \mathrm{~min}$ to $450^{\circ} \mathrm{C}$, and kept at this temperature for $4 \mathrm{hr}$. Mineralization was considered completion when ash was white or slightly colored, with no charred particles. The ash was dissolved in $1 \mathrm{ml} \mathrm{HCl}$ and transferred with deionized water into $10.0 \mathrm{ml}$ volumetric flask. For ICP-OES spectrometric measurements (Optima 3000 DV; Perkin Elmer Corp., Norwalk, CT). Details on ICP-OES instrumental operating conditions and measuring parameters used are given in Table 1.

\section{Analysis}

The working multi-elemental standard solutions were made with $10 \% \mathrm{HCl}$. All working standard solutions were stored in Nalgene polypropylene bottles. The calibration curve was made from 5 points and the blank. The multi-elemental standard solutions ranged from 2.5 to $100.0 \mathrm{mg} / 1$ for $\mathrm{Ca}, \mathrm{K}$, and $\mathrm{P}$; $0.25-10.0 \mathrm{mg} / \mathrm{l}$ for $\mathrm{Fe}, 0.625-25.0 \mathrm{mg} / \mathrm{l}$ for $\mathrm{Mg}$; and $0.0125-0.5 \mathrm{mg} / \mathrm{l}$ for $\mathrm{Mn}$. The collected data were analyzed by using SAS package (version 8.0 , SAS Institute

Table 1. ICP-OES operating conditions

\begin{tabular}{ll}
\hline Parameter & Operation conditions \\
\hline RF power, W & 1350 \\
Sample uptake rate, $\mathrm{ml} / \mathrm{min}$ & 1.5 \\
Nebulization gas flow rate, L/min & 0.85 \\
Plasma flow rate, L/min & 15 \\
Sample flow rate, L/min & 115 \\
Observation height & $15 \mathrm{~mm}$ above load coil \\
Nebulizer & Cross flow \\
Spray chamber & Scott \\
Elements, wavelengths $(\mathrm{nm})$ & $\mathrm{Ca}(422.673), \mathrm{Fe}(259.940), \mathrm{K}(766.491), \mathrm{Mg}(280.270), \mathrm{Mn}(257.610), \mathrm{P}(213.618)$ \\
\hline
\end{tabular}




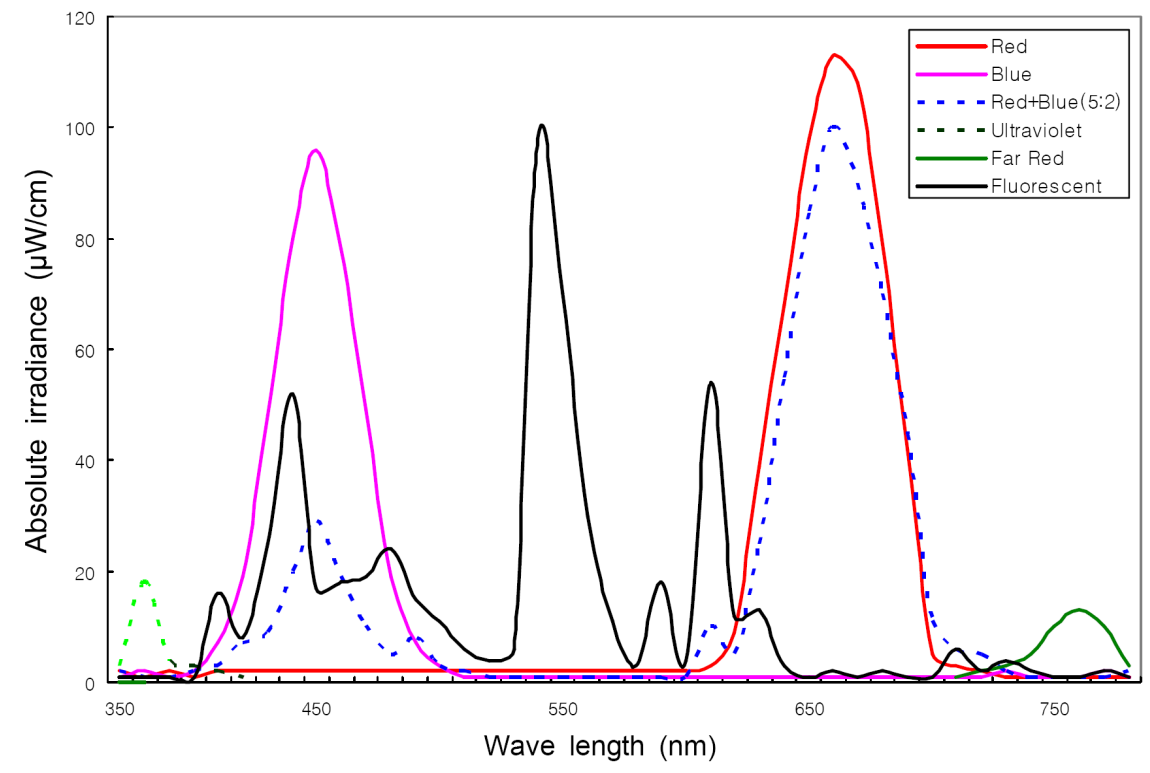

Fig. 1. Absolute PPF spectral distribution balance of LEDs and fluorescent light at the centre of growth areas(The wavelength of each LED used in this study was 450 and $660 \mathrm{~nm}$ in red, $450 \mathrm{~nm}$ in blue, 450 and $660 \mathrm{~nm}$ in red+blue, $350 \mathrm{~nm}$ in ultraviolet, and $730 \mathrm{~nm}$ in far-red light).

Inc., Cary, NC) for Duncan's multiple range tests.

\section{Results and Discussion}

\section{Effect of growth}

The wavelength of each LED used in this study was 450 and $660 \mathrm{~nm}$ in red, $450 \mathrm{~nm}$ in blue, 450 and $660 \mathrm{~nm}$ in red+blue, $350 \mathrm{~nm}$ in ultraviolet, and $730 \mathrm{~nm}$ in far-red light (Fig. 1).

The PPF irradiance in red, blue, red+blue, fluorescent, ultraviolet, and far-red was 172, 192, 169, $163 \mu \mathrm{mol} \cdot \mathrm{m}^{-2}$. $\mathrm{s}^{-1}$, and $5.1^{-3}, 497.7 \mathrm{w} \cdot \mathrm{m}^{-2}$ respectively. The plant height, hypocotyl length, leaf characteristics, and fresh weight cultivated by various LEDs light radiation are shown in Table 2. Plant height of lettuce grown under red, blue, red-blue, ultraviolet, far-red and fluorescent light radiation were 13.3, 8.8, 9.1, 10.8, 6.2 and $14.2 \mathrm{~cm}$, respectively.

Plant height of length cultivated by red and fluorescent showed the highest score compared with other samples.
Hypocotyl length was measured following 30 days of growth. Elongation of the hypocotyl was significantly affected by only red light irradiation. There was no measurable change in five light irradiation except for red light. No elongation of hypocotyl was observed in blue, red+blue, ultraviolet, far-red and fluorescent light irradiations.

A large number of leaves were founded when the seedlings were grown under red+blue and fluorescent. Very small number of leaf was produced by far-red light irradiation. Leaf length of lettuce seedlings were decreased by far-red light irradiation and meanwhile it was significantly increased by red and fluorescent.

Lee et al. (2010) reported that plant growth like a leaf length and fresh weight is more stimulated in red+blue light than that of fluorescent light under same photon flux, although the photosynthetic photon flux of fluorescent light irradiation $\left(163 \mu \mathrm{mol} \cdot \mathrm{m}^{-2} \cdot \mathrm{s}^{-1}\right)$ was similar to red+blue light $\left(169 \mu \mathrm{mol} \cdot \mathrm{m}^{-2} \cdot \mathrm{s}^{-1}\right)$. Similarly to the leaf length, the longer leaf diameter of lettuce plants grown under red,

Table 2. Effects of light emitting diode on growth of 'Oak Leaf' lettuce at 30 days after treatment

\begin{tabular}{|c|c|c|c|c|c|c|}
\hline $\begin{array}{l}\text { Radiation } \\
\text { light }\end{array}$ & $\begin{array}{l}\text { Plant height } \\
(\mathrm{cm})\end{array}$ & $\begin{array}{l}\text { Hypocotyl } \\
\text { length }(\mathrm{cm})\end{array}$ & No. of leaf & $\begin{array}{l}\text { Leaf length } \\
(\mathrm{cm})\end{array}$ & $\begin{array}{l}\text { Leaf dia. } \\
\quad(\mathrm{cm})\end{array}$ & $\begin{array}{c}\text { Fresh weight } \\
\text { (g/plant) }\end{array}$ \\
\hline Red & $13.3 \mathrm{az}$ & $1.9 \mathrm{a}$ & $4.4 \mathrm{~b}$ & $13.3 \mathrm{a}$ & $3.7 \mathrm{a}$ & $2.6 \mathrm{a}$ \\
\hline Blue & $8.8 \mathrm{c}$ & $0.0 \mathrm{~b}$ & $4.3 \mathrm{~b}$ & $8.9 \mathrm{c}$ & $3.4 \mathrm{a}$ & $1.5 \mathrm{~b}$ \\
\hline Red+blue & $9.1 \mathrm{c}$ & $0.0 \mathrm{~b}$ & $5.7 \mathrm{a}$ & $9.0 \mathrm{c}$ & $4.1 \mathrm{a}$ & $3.3 \mathrm{a}$ \\
\hline Ultraviolet & $10.8 \mathrm{~b}$ & $0.0 \mathrm{~b}$ & $3.8 \mathrm{~b}$ & $10.8 \mathrm{~b}$ & $2.7 \mathrm{~b}$ & $0.7 \mathrm{~b}$ \\
\hline Far-red & $6.2 \mathrm{~d}$ & $0.0 \mathrm{~b}$ & $2.0 \mathrm{c}$ & $0.9 \mathrm{~d}$ & $0.4 \mathrm{c}$ & $0.0 \mathrm{c}$ \\
\hline Fluorescent & $14.2 \mathrm{a}$ & $0.0 \mathrm{~b}$ & $5.3 \mathrm{a}$ & $14.2 \mathrm{a}$ & $4.1 \mathrm{a}$ & $3.0 \mathrm{a}$ \\
\hline
\end{tabular}

${ }^{\mathrm{z}}$ Means separation within columns by Duncan's multiple range test at $5 \%$ level. 


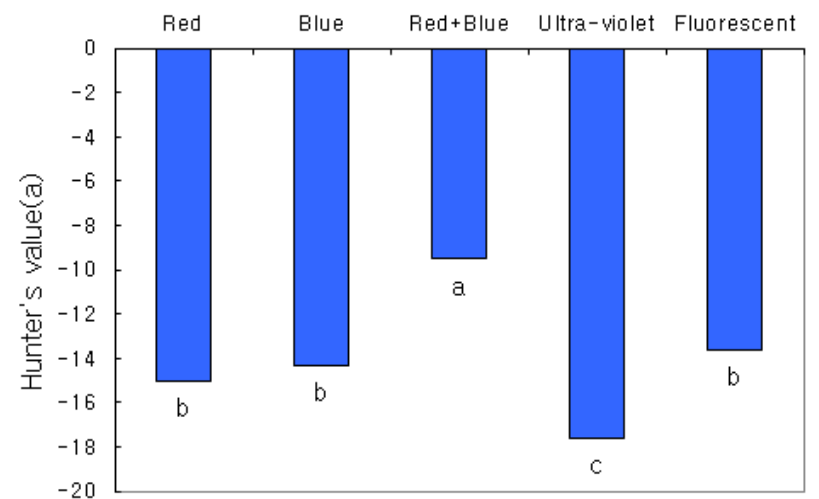

Fig. 2. Effects of LED radiation light on Hunter's values of 'Oak Leaf' lettuce. Changes in the Hunter color value of leaf lettuce cultivated by various LED irrigations are shown.

red+blue, and fluorescent light irradiation has resulted in more compact foliage and improved morphology in comparison with plants grown in ultraviolet and far-red light irradiation.

Pinho et al. (2007) showed that red+blue light irradiation causes an increased leaf diameter and number in lettuce plants [11]. The higher increment of fresh weight grown in LEDs light irradiation was observed in red+blue, red, and fluorescent light irradiation, in turn.

\section{Effect of quality}

Changes in the Hunter color value of leaf lettuce cultivated by various LED irrigations are shown in Fig. 2. The LED irradiation during the cultivation induced the color change of the samples. Redness $\left(a^{*}\right)$ of lettuce leaf in the treatments of red+blue light was higher than that of red, blue, ultraviolet and fluorescent light irradiation. Zhou and Singh (2004) reported that amount of each individual anthocyanin of cranberry increased differently under natural light, red, and far-red light, suggesting that expressions of enzymes that catalyze the anthocyanin biosynthesis are

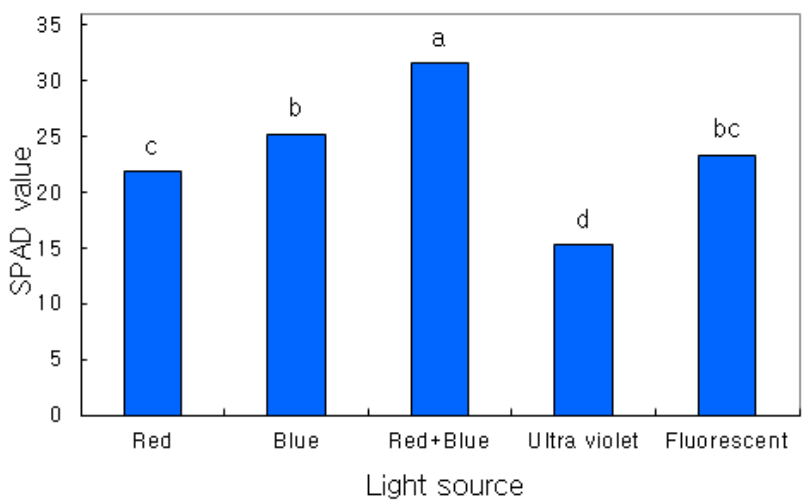

Fig. 3. Effects of LED radiation light on SPAD values of 'Oak Leaf' lettuce. The SPAD values of lettuce grown under red, blue, red+blue, u ltraviolet, and fluorescent light irradiation.

regulated differently by environments [13]. The results were agreement with the results of Lee et al. (2010) that the red+blue light irradiation increased significantly anthocyanin content in leaf lettuce [4].

Fig. 3 shows the SPAD values of lettuce grown under red, blue, red+blue, u ltraviolet, and fluorescent light irradiation. Highest SPAD values were recorded in red+blue light irradiation. The SPAD values were higher in red, blue, red+blue light irradiation as compared with the fluorescent light except for ultraviolet light. The effect of irradiance on SPAD values are used for the estimation of the nitrogen status of crops. Most crops are sun adapted plants in which leaf transmittance is less affected by irradiance than in shade plants $[3,10]$ and SPAD values are therefore probably not affected by irradiance in rice plant. However, in lettuce plant grown in various LEDs irradiation, the SPAD values are significantly affected by LEDs light irradiation.

Changes in seven kinds of inorganic elements in lettuce seedlings grown under different LEDs light irradiation were shown in Table 3 . The red, blue and ultraviolet light irradiation caused an increased $\mathrm{N}$ content in lettuce seedlings.

Table 3. Effect of light emitting diodes on mineral absorption in lettuce seedlings

\begin{tabular}{lcccccrcr}
\hline \multirow{2}{*}{ Radiation light } & $\mathrm{N}$ & $\mathrm{P}$ & $\mathrm{K}$ & $\mathrm{Ca}$ & $\mathrm{Mg}$ & $\mathrm{Mn}$ & $\mathrm{Fe}$ \\
\cline { 2 - 8 } & \multicolumn{7}{c}{$\mathrm{mg} \cdot \mathrm{kg}^{-1}$} \\
\hline Red & $990 \mathrm{az}$ & $78.1 \mathrm{ab}$ & $0.34 \mathrm{a}$ & $41.6 \mathrm{~b}$ & $149.8 \mathrm{c}$ & $7.5 \mathrm{c}$ & $3.3 \mathrm{~d}$ \\
Blue & $895 \mathrm{a}$ & $70.2 \mathrm{bc}$ & $0.39 \mathrm{a}$ & $35.1 \mathrm{c}$ & $183.1 \mathrm{a}$ & $21.5 \mathrm{a}$ & $5.1 \mathrm{~b}$ \\
Red+blue & $357 \mathrm{c}$ & $62.8 \mathrm{c}$ & $0.36 \mathrm{a}$ & $51.8 \mathrm{a}$ & $196.7 \mathrm{a}$ & $15.2 \mathrm{~b}$ & $6.7 \mathrm{a}$ \\
Ultraviolet & $761 \mathrm{~b}$ & $79.7 \mathrm{ab}$ & $0.40 \mathrm{a}$ & $40.8 \mathrm{~b}$ & $157.2 \mathrm{c}$ & $6.9 \mathrm{c}$ & $4.2 \mathrm{c}$ \\
Fluorescent & $756 \mathrm{~b}$ & $85.4 \mathrm{a}$ & $0.34 \mathrm{a}$ & $41.3 \mathrm{~b}$ & $171.5 \mathrm{~b}$ & $23.7 \mathrm{a}$ & $3.2 \mathrm{~d}$ \\
\hline
\end{tabular}

${ }^{\mathrm{z}}$ Means separation within columns by Duncan's multiple range test at $5 \%$ level. 


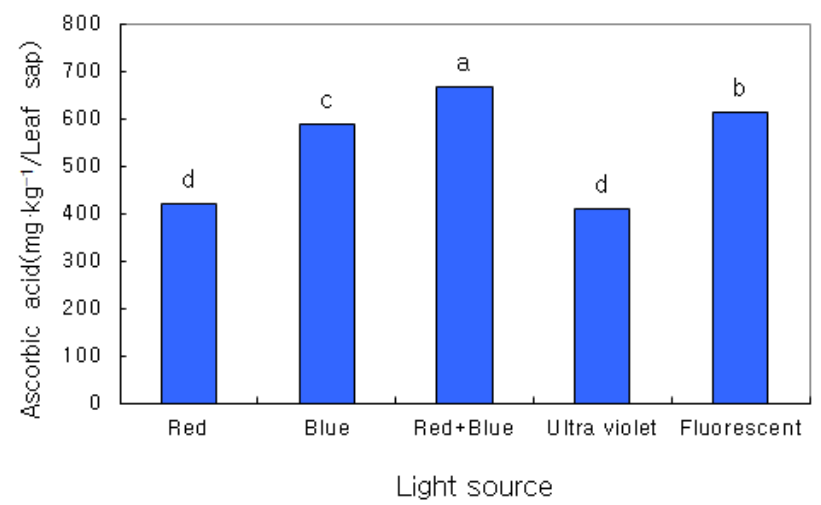

Fig. 4. Ascorbic acid content of 'Oak Leaf' lettuce under different radiation lights. As one of the functional nutrients, ascorbic acid content was measured in leaf of lettuce plants grown under different LEDs light irradiation.

Otherwise the red+blue light irradiation showed $2.5 \sim 2.8$ times lower than that of red and blue light irradiation, respectively. In the changes of $\mathrm{P}$ content, LEDs light irradiation showed low P level compared with that of fluorescent light irradiation. The $\mathrm{Ca}$ and $\mathrm{Mg}$ content was only increased by red+blue light irradiation. The Mn content was increased in the treatment of blue and fluorescent light irradiation and decreased red and ulraviolet light irradiation. The Fe content in lettuce seedlings ranged from 3.2 to $6.7 \mathrm{mg} \cdot \mathrm{kg}^{-1}$.

As one of the functional nutrients, ascorbic acid content was measured in leaf of lettuce plants grown under different LEDs light irradiation (Fig. 4). Red+blue and fluorescent light irradiation showed highest ascorbic acid contents, meanwhile red, blue and ultraviolet light irradiation caused lower ascorbic acid content compared with red+blue and fluorescent light irradiation. Nam et al. (2004) reported that far-red radiation significantly increased the antioxidant activity of rice hull extracts [8].

Detailed studies are required regarding the application of LED light for seedling growth, inorganic elements, antioxidative compounds including ascorbic acid in terms of economic utility, nutrition enhancement, and the correlation between light quality and growth of colored lettuce seedling.

\section{Acknowledgment}

The study was supported by the Cooperative Research Project (PJ 907022122012), Rural Development Administration, Republic of Korea.

\section{References}

1. Barta, D. J., Tibbitts, T. W., Bula, R. J. and Morrow, R. C. 1992. Evaluation of light emitting diode characteristics for a space-based plant irradiation source. AdV Space Res 12, 141-149.

2. Bula, R. J., Morrow, R. C., Tibbitts, T.W., Bula, R. J., Barta, D. J., Ignatius, R. W. and Martin, T. S. 1991. Light-emitting diodes as a radiation source for plants. HortScience 26, 203-205.

3. Inoue, Y. and Shibata, K. 1974. Comparative examination of terrestrial plant leaves in terms of light-induced absorption changes due to chloroplast rearrangements. Plant Cell Physiol 15, 717-721.

4. Lee, J. G., Oh, S. S., Cha, S. H., Jang, Y. A., Kim, S. Y., Um, Y. C. and Cheong, S. Y. 2010. Effects of red/blue light ratio and short-term light quality conversion on growth and anthocyanin contents of baby leaf lettuce. J Bio-Env Con 19, 351-359.

5. Lee, G. J., Shin, H. M., Kim, K. S., Lee, C. H. and Kim, J. H. 1999. Effects of added chlorides and their concentrations on growth and nitrate content in leaf lettuce(Lactuca sativa L.) in hydroponics. Plant Res 2, 26-30.

6. Lee, J. G., Lee, B. Y. and Lee, H. J. 2006. Accumulation of phytotoxic organic acids in reused nutrient solution during hydroponic cultivation of lettuce (Lactuca sativa L.). SciHort 110, 119-128.

7. Mc Cree, K. J. 1972. The action spectrum, absorbance and quantum yield of photosynthesis in crop plants. Agric Meteorol 9, 191-216.

8. Nam, K. C., Kim, J. H., Ahn, D. U. and Lee, S. C. 2004. Far-infrared radiation increases the antioxidant properties of rice hull extract in cooked turkey meat. J Agric Food Chem 52, 374-379.

9. Park, K. W. and Lee, J. M. 2006. Wrap-ups: A unique method of vegetable usage and consumption in Korea. Chronica Hort 46, 13-15.

10. Park, Y. I., Chow, W. S. and Anderson, J. M. 1996. Chloroplast movement in the shade plant Tradescantia albiflora helps protect photosystem II against light stress. Plant Physiol 111, 867-875.

11. Pinho, P., Lukkala, R., Sarkka, L., Tetri, E., Tahvonen, R. and Halonen, L. 2007. Evaluation of lettuce growth under multi-spectral-component supplemental solid state lighting in greenhouse environment. IREE 2, 22-29.

12. Yorio, N. C., Goins, G. D., Kagie, H. R., Wheeler, R. M. and Sager, J. C. 2001. Improving spinach, radish, and lettuce growth under red light-emitting diodes (LEDs) with blue light supplementation. HortScience 36, 380-383.

13. Zhou, Y. and Singh, B. R. 2004. Effect of light on anthocyanin levels in submerged, harvested Cranberry fruit. $J$ Biomed Biotechnol 5, 259-263. 


\section{초록 : LED 처리가 상추의 생육 및 품질에 미치는 영향}

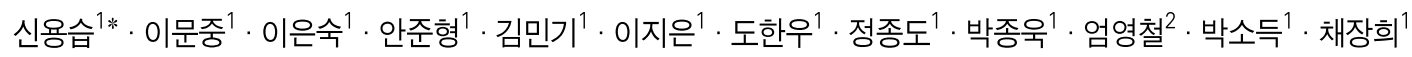
('경상북도 농업기술원, ${ }^{2}$ 농촌진흥청 국립원예특작과학원)

식물공장 내 적색광, 청색광, 적청 혼합광, 자외선, 적외선, 형광등의 광원을 달리하여 어린잎 상추의 생육과 무기성분 흡수를 검토하였다. 잎의 형태는 Red 파장에서 초장 및 하배축의 길이신장이 촉진되어 도장하였고 Far red에서는 생장이 불가능하였으나 Red+Blue의 혼합광원에서는 초장이 짧고 엽수가 많고 생체중이 증가하여 상추 의 형태 및 발달 차원에서 유의적으로 좋았다. 광질에 따른 어린잎 상추의 색차 및 상대 엽록소 함량을 조사한 결과, 적색도를 나타내는 Hunter a* 값은 Red+Blue 혼합광 및 형광등에서 높았고 적색광 및 자외선에서는 낮게 나타났는데 상대 엽록소 함량을 나타내는 SPAD도 같은 경향이었다. 특히 상대엽록소 함량은 형광등의 23.3에 비 해 혼합광에서 1.4 배 향상된 적색도를 나타내었다. 광원별 상추의 무기물 함량을 조사한 결과, $\mathrm{pH}$ 및 $\mathrm{K}$ 함량은 모든 처리에서 차이가 없었으나 $\mathrm{N}, \mathrm{Ca}, \mathrm{Mg}, \mathrm{Fe}, \mathrm{Ascorbic}$ acid 함량은 LED 처리구에서 많았고 $\mathrm{P}$ 함량은 형광등 처리구에서 많았다. 이상의 결과를 요약하면 단색광에 비하여 Red+Blue 혼합광에서 상추의 생육이 우수하고 무 기물 함량이 증대되어 식물공장 내 생산성 향상을 위해서는 혼합광 조절로 상품성 있는 고품질의 상추 생산이 가능 할 것으로 생각되었다. 